\title{
Pelaksanaan pembelajaran jarak jauh bagi anak berkebutuhan khusus (Survei terhadap orangtua dan guru di Lampung)
}

\author{
Ossy Firstanti Wardany ${ }^{1}$, Yulvia Sani ${ }^{2}$ \\ ${ }^{1,2}$ Universitas Muhammadiyah Lampung, Bandar Lampung, 35132, Indonesia. \\ * Corresponding Author. E-mail:ossyfirstan@gmail.com
}

\begin{abstract}
Abstrak:Pembelajaran Jarak Jauh (PJJ) menjadi solusi menjembatani keharusan untuk berada di rumah untuk menghindari penularan Covid-19 dan tepat memberikan pelayanan pembelajaran bagi anak berkebutuhan khusus (ABK). Penelitian merupakan penelitian survei yang dilakukan terhadap 58 guru dan 36 orangtua ABK di Provinsi Lampung. Tujuan penelitian adalah menggali bagaimana pelaksanaan pengalaman, dan permasalahan terkait PJJ melalui sudut pandang orangtua dan guru ABK. Hasil menunjukkan selama pandemi Covid-19, PJJ dilaksanakan dalam bentuk pembelajaran daring. Guru mengungkapkan bahwa permasalah terkait sinyal internet, kesiapan anak dalam belajar, kondisi dan kemampuan orangtua dalam membimbing anak menjadi penentu keberhasilan PJJ bagi ABK. PJJ memerlukan pendampingan dari orangtua. dan pada pelaksanaan terdapat kendala terkait konektivitas internet, waktu yang dimiliki, keadaan emosi dan kesiapan anak belajar daridi rumah, serta kompetensi dan kemampuan orangtua dalam pengasuhan anak dan pembelajaran ABK di rumah. Guru dan orangtua diharapkan memiliki kompetensi dan keterampilan dalam mendampingi ABK belajar, mengelola perilaku, mengatur seting belajar, mengakses teknologi, serta kesediaan berkolaborasi. Sehingga, berbagai pelatihan terkait penggunaan teknologi, pengasuhan anak, dan pelatihan mengajar jarak jauh sangat diperlukan baik bagi guru, maupun bagi orangtua.
\end{abstract}

Kata kunci: pembelajaran jarak jauh, anak berkebutuhan khusus, Covid-19, pendampingan orangtua, peran guru

\section{The implementation of distance learning for children with special needs (Survey of parents and teachers in Lampung)}

\begin{abstract}
Distance Learning is a solution to bridge the need to be stay at home to avoid Covid-19 transmission and to provide appropriate learning services for children with special needs.This is a survey research that has been conducted on 58 teachers and 36 parents of children with special needs in Lampung Province.The purpose of research is to explore how perceptions, experiences and problems related to distance learning through the perspective of parents and teachers of children with special needs. The results show that during the Covid-19 pandemic, distance learning was carried out in the form of online learning. However, the teacher revealed that problems related to poor internet signals, the readiness of children in learning, the conditions and the ability of parents to guide children are critical determinants of success for children with special needs.Distance learning requires the assistance of parents, and in practice still found problems related to internet connectivity, time owned, emotional state and readiness of children to learn from home, as well as the competence and ability of parents in child care and teaching of children with special needs at home. Teachers and parents should have competence and skills in assisting children with special needs when learning, modifying children's behavior, adaptive learning settings, accessing technology, and the ability to collaborate with each other.Various training related to the use of technology, childcare, and distance teaching are needed both for teachers and parents.
\end{abstract}

Keywords: distance learning, children with special needs, Covid-19, parental assistance, teacher roles

\section{PENDAHULUAN}

Coronavirus disease 2019 (Covid-19) atau Severe Acute Respiratory Syndrome Coronavirus 2 (SARS-CoV-2) merupakan wabah virus yang pertama kali terjadi di Wuhan, Cina pada penghujung 2019. Virus tersebut kemudian menyebar ke negara-negara lain. Pada 11 Maret 2020, WHO menyatakan bahwa Covid-19 adalah pandemi (Sheposh, 2020). Menurut Kementrian Kesehatan Indonesia (2020) Covid-19 dapat menular dari manusia ke manusia melalui percikan batuk/bersin (droplet). Orang yang paling berisiko tertular penyakit ini adalah orang yang kontak erat dengan pasien Covid-19 termasuk yang merawat pasien Covid-19. Para pakar kesehatan merekomendasikan tindakan pecegahan virus ini melalui rajin mencuci tangan, tidak menyentuh wajah, membersihkan lingkungan rumah, menggunakan 


\section{JPK (Jurnal PendidikanKhusus), 16 (2), 2020 - 49}

Ossy Firstanti Wardany, Yulvia Sani

tisu saat bersin, dan anjuran untuk di rumah saja (Sheposh, 2020). Penyebaran Covid-19 begitu masif, pada 2 Maret 2020, Indonesia melaporkan kasus konfirmasi Covid-19 pertama sebanyak 2 kasus di Jakarta (Kementerian Kesehatan RI, 2020). Virus tersebut menyebar sampai Lampung dan pada 19 Maret 2020, Dinas Kesehatan Provinsi Lampung melaporkan satu kasus positif yang berkontak dengan penderita Covid-19 lain dalam sebuah seminar di Bogor (Tim Detik, 2020). Kemunculan kasus positif tersebut mengakibatkan Pemerintah Provinsi Lampung mengeluarkan Surat Pencegahan Penyebaran Virus Covid-19 bernomor 420/808/V.01/2020. Surat tersebut meminta agar semua jenjang pendidikan yang ada di Provinsi Lampung melakukan pembelajaran di rumah sejak 27 Maret 2020 (Isworo, 2020). Hal tersebut merupakan kelanjutan dari Surat Edaran Mendikbud No 4 Tahun 2020 Tentang Pelaksanaan Kebijakan Pendidikan Dalam Masa Darurat Penyebaran Covid-19. Kedua surat tersebut menjadi dasar terselenggaranya kebijakan belajar dari rumah atau pembelajaran jarak jauh.

Pembelajaran jarak jauh (PJJ) merupakan bentuk dari pelayanan pendidikan bagi siswa yang mengalami hambatan jarak. PJJ menjembatani antara keharusan untuk berada di rumah dari menghindari penularan Covid-19, tetapi tetap memberikan pelayanan pembelajaran bagi anak. Pendidikan bertujuan mengembangkan membangun kemandirian, dan meningkatkan keterampilan adaptif pada setiap anak. Oleh karenanya, belajar merupakan hak bagi setiap siswa, termasuk anak berkebutuhan khusus. Menurut Kaplan (Tanduklangi \& Amri, 2019). PJJ adalah pendekatan pengajaran dimana siswa tidak hadir secara fisik di sekolah. PJJ terjadi ketika guru dan siswa dipisahkan ruang dan waktu, bersifat interaktif, dan interaksi antara guru dan siswa dimediasi dengan satu atau lebih teknologi (Cavanaugh, 2006; Laudato, 2002). Keuntungan dari PJJ adalah adanya fleksibilitas, aksesibilitas, kemampuan untuk menciptakan lingkungan belajar yang serba mandiri, dan lebih sedikit waktu yang terbuang (McVey, 2008). Akan tetapi, McVey juga menyebutkan bahwa kerugiaan PJJ berkenaan dengan hilangnya hak belajar bagi siswa yang memiliki motivasi dan disiplin yang rendah dalam belajar, di mana hal ini dipengaruhi bagaimana guru terlatih menyampaikan dan membuat pembelajaran yang bermakna selama PJJ.

Pembelajaran yang bermakna dapat diimplementasi apabila guru dan siswa dapat berinteraksi dan membangun ikatan yang kuat. Chakraborty \& Nafukho (2014) menyebutkan ada lima hal yang harus dilakukan guru dalam memperkuat ikatan dengan siswa, yaitu (1) menciptakan dan memelihara lingkungan belajar yang positif; (2) membangun komunitas belajar; (3) memberikan umpan balik yang konsisten secara tepat waktu; (4) mempraktekkan fleksibilitas menggunakan teknologi untuk memberikan konten yang tepat; dan (5) menyediakan sistem dukungan yang tepat. Interaksi dan ikatan tersebut dapat terbangun apabila pada pelaksanaan PJJ, pembelajaran dapat berlangsung secara interaktif. Cavanaugh (2006) menyebutkan bahwa PJJ yang interaktif dapat dilakukan melalui berbagai cara seperti melalui chat, telepon, audio conference, video conference, atau broadcast audio dan video. Pada anak-anak termasuk ABK, adanya orangtua sangat berperan dalam mendampingi pembelajaran dan menjadi penghubung antara guru dan anak. Hal ini baik mengenai penggunaan teknologi, maupun pendampingan saat belajar.

Keberhasilan PJJ tergantung beberapa faktor seperti keterampilan yang diperlukan dalam belajar dan komunikasi, adaptasi teknologi dalam seting sosial, mengaitkan pembelajaran ke dalam aktivitas yang relevan, dan keterampilan mencari sumber belajar yang baik (Cavanaugh, 2006). Keterampilanketerampilan tersebut tentunya menjadi permasalahan tersendiri bagi anak berkebutuhan khusus (ABK). Sebagai contoh, salah kriteria utama anak autis adalah memiliki hambatan komunikasi. Sedangkan berdasarkan teori Cavanaugh tersebut, keterampilan komunikasi adalah salah satu penentu keberhasilan PJJ. Berdasarkan contoh tersebut, tentu saja akan menjadi permasalahan ketika PJJ bagi ABK dilaksanakan tanpa pendampingan orangtua, pengasuh, atau orang terdekat lain. Tak hanya itu, kondisi antara rumah dan sekolah yang berbeda tentu membutuhkan adaptasi dan penyesuaian bagi ABK. Pembelajaran ABK yang tidak hanya akademik, tetapi juga berkaitan dengan perkembangan barang tentu membutuhkan keterampilan khusus. Keadaan emosi dan perilaku yang terkadang tidak stabil dan memiliki permasalahan tertentu pun dapat menjadi problem saat belajar di rumah. Karenanya, kemampuan dan keterampilan membimbing ABK saat belajar, manajemen perilaku dan modifikasi perilaku, kemampuan mengaitkan pembelajaran kontekstual dengan kehidupan di rumah, serta kemamapaun menyiapkan situasi belajar yang kondusif menjadi keterampilan yang penting bagi orangtua atau orang terdekat di rumah. Subarto (2020) menegaskan bahwa orangtua memiliki peran penting dalam membangun regulasi diri anak dan penguatan selama pembelajaran di rumah. 
Pembelajaran pada ABK sudah tentu memiliki banyak tantangan, terlebih jika dilakukan melalui pembelajaran jarak jauh (PJJ). Peran guru maupun orangtua begitu penting dalam pelaksanaan pembelajaran jarak jauh di masa pandemi Covid-19 ini. Guru harus dapat menciptakan PJJ yang bermakna bagi ABK dan orangtua perlu memiliki kesiapan dan keterampilan dasar dalam menangani pembelajaran bagi anaknya. Berlatar belakang hal tersebut, peneilitian bertujuan untuk mengetahui bagaimana pelaksanaan pembelajaran jarak jauh pada anak berkebutuhan khusus, khususnya di Provinsi Lampung. Penelitian bermaksud menggali bagaimana pelaksanaan, pengalaman dan permasalahan terkait PJJ melalui sudut pandang orangtua dan guru anak berkebutuhan khusus.

\section{METODE}

Jenis penelitian yang dilakukan merupakan penelitian survei dengan subjek penelitian adalah orangtua dan guru anak berkebutuhan khusus di Lampung. Survei dilakukan dengan menyebarkan angket melalui Google Form terhadap guru dan orangtua anak berkebutuhan khusus di Lampung. Google Form atau Google Formulir adalah fitur di Google yang bertujuan untuk memudahkan membuat survei melalui internet (Sudaryo, Sofiati, Medidjati \& Hadiana, 2019). Sampel dalam penelitian ini dipilih secara random sampling dengan kriteria sebagai guru anak berkebutuhan khusus atau orangtua anak berkebutuhan khusus di Lampung. Pelaksanaan penyebaran angket dilakukan pada tanggal 1 sampai dengan 5 Mei 2020.

Metode dalam penelitian terdiri dari kuantitatif dan data kualitatif berdasarkan jenis pertanyaan yang diberikan, yaitu pertanyaan terbuka dan tertutup. Metoda kuantitatif digunakan saat menghitung jumlah pilihan jawaban responden dengan cara tabulasi data dan presentase jawaban yang masuk. Metode kualitatif digunakan untuk menganalisa jawaban dari pertanyaan terbuka yang diberikan.

Aspek survei yang diberikan pada guru lebih dikaitkan dengan pelaksanaan PJJ, sedangkan pada orangtua berkaitan dengan pendampingan mereka terhadap anak berkebutuhan khusus selama PJJ. Adapun kisi-kisi survei untuk guru dan orangtua dapat dilihat pada tabel 1.

Tabel 1. Kisi-Kisi Survei untuk Guru dan Orangtua

\begin{tabular}{lll}
\hline No & Guru & Orangtua \\
\hline 1 & Profil/latar belakang guru & Profil orangtua dan siswa \\
& $\begin{array}{l}\text { Adanya PJJ selama pandemi dan sosialisasi PJJ } \\
\text { dari sekolah }\end{array}$ & $\begin{array}{l}\text { Pelaksanaan PJJ (jadwal, durasi, metode, media, } \\
\text { materi) }\end{array}$ \\
& Jadwal, waktu, durasi pelaksanaan PJJ & Pengalaman orangtua saat mendampingi PJJ \\
3 & Media komunikasi yang digunakan, metode & Kendala dan permasalahan dalam mendampingi \\
pembelajaran, materi dan pelaksanaan & anak saat PJJ
\end{tabular}

Pertanyaan pada responden guru berjumlah 30 dengan pertanyaan terbuka sebanyak 28 dan pertanyaan tertutup atau kategorial berjumlah 12. Pertanyaan dengan responden orangtua berjumlah 24 pertanyaan, terdiri dari 17 pertanyaan tertutup atau kategorial dan sisanya merupakan pertanyaan terbuka. Analisa data dilakukan secara kuantitatif dan kualitatif bergantung pertanyaan yang diajukan. Analisa kuantitatif berdasarkan data persentase yang didapatkan. Sedangkan analisa kualitatif dilakukan berdasarkan jawaban responden.

\section{HASIL DAN PEMBAHASAN}

\section{Profil Responden Orangtua}

Berdasarkan data yang masuk pada 1-5 Mei 2020, jumlah responden yang mengisi kuisioner sebanyak 36 orang. Sebanyak $29(80,6 \%)$ orang sebagai Ibu anak berkebutuhan khusus, dan sisanya 7 orang $(19,4 \%)$ sebagai ayah. Beberapa informasi terkait usia orangtua, pekerjaan, dan persebaran kabupaten tempat tinggal dapat dilihat pada tabel 2. 
JPK (Jurnal PendidikanKhusus), 16 (2), 2020 - 51

Ossy Firstanti Wardany, Yulvia Sani

\begin{tabular}{|c|c|c|c|c|c|c|c|c|}
\hline & \multicolumn{8}{|c|}{ Usia orangtua (dalam tahun) } \\
\hline & $25-30$ & $31-35$ & & $36-40$ & $41-45$ & \multicolumn{2}{|c|}{$46-50$} & $\begin{array}{c}50 \mathrm{ke} \\
\text { atas }\end{array}$ \\
\hline$\sum$ & 2 & 2 & & 17 & 5 & \multirow{2}{*}{\multicolumn{2}{|c|}{$\begin{array}{c}6 \\
(17 \%) \\
\end{array}$}} & 4 \\
\hline$\overline{\%}$ & $(6 \%)$ & $(6 \%)$ & & $(47 \%)$ & $(14 \%)$ & & & $(11 \%)$ \\
\hline \multicolumn{9}{|c|}{ Pekerjaan Orangtua } \\
\hline & $\begin{array}{c}\text { PNS/ } \\
\text { BUMN }\end{array}$ & $\begin{array}{c}\text { TNI/ } \\
\text { POLRI }\end{array}$ & $\begin{array}{l}\text { Guru/ } \\
\text { Dosen }\end{array}$ & $\begin{array}{l}\text { Karya- } \\
\text { wan }\end{array}$ & Wiraswasta & Pedagang & $\begin{array}{c}\text { Ibu/ayah } \\
\text { rumah tangga }\end{array}$ & $\underset{\mathrm{h}}{\mathrm{Buru}}$ \\
\hline $\begin{array}{l}\sum_{\%} \\
\%\end{array}$ & $\begin{array}{c}3 \\
(9,3 \%)\end{array}$ & $\begin{array}{c}2 \\
(5,6 \%)\end{array}$ & $\begin{array}{c}2 \\
(5,6 \%)\end{array}$ & $\begin{array}{c}4 \\
(11,1 \%)\end{array}$ & $\begin{array}{c}3 \\
(8,3 \%)\end{array}$ & $\begin{array}{c}1 \\
(2,8 \%)\end{array}$ & $20(55,6 \%)$ & $\begin{array}{c}1 \\
(2,8 \\
\%)\end{array}$ \\
\hline & \multicolumn{8}{|c|}{ Tempat Tinggal (Kabupaten) } \\
\hline & $\begin{array}{c}\text { Bandar } \\
\text { Lampung }\end{array}$ & $\begin{array}{l}\text { Lampung } \\
\text { Tengah }\end{array}$ & $\begin{array}{l}\text { Lampung } \\
\text { Utara }\end{array}$ & Metro & $\begin{array}{c}\text { Lampung } \\
\text { Selatan }\end{array}$ & Tanggamus & $\begin{array}{l}\text { Lampung } \\
\text { Timur }\end{array}$ & $\begin{array}{l}\text { Pesawa- } \\
\text { ran }\end{array}$ \\
\hline $\begin{array}{l}\sum \\
\%\end{array}$ & $\begin{array}{c}12 \\
(33,3 \%)\end{array}$ & $\begin{array}{c}9 \\
(25 \%)\end{array}$ & $5(13,9 \%)$ & $\begin{array}{c}4 \\
(11,1 \%)\end{array}$ & $2(5,6 \%)$ & $2(5,6 \%)$ & $1(2,8 \%)$ & $1(2,8 \%)$ \\
\hline
\end{tabular}

Berdasarkan Tabel 2 terlihat bahwa orangtua memiliki latar belakang yang cukup beragam. Sebagian besar orangtua berada di usia 30 sampai 40 tahun. Selain itu, separuh dari responden merupakan ibu atau ayah rumah tangga yang memang sebelum adanya pandemi telah berada di rumah. Jumlah responden yang masuk tidaklah merata secara daerah tempat tinggal. Responden cukup banyak dari Bandar Lampung dan Lampung Tengah dibandingkan dengan daerah lain. Selanjutnya, data mengenai anak berkebutuhan khusus dari responden dapat dilihat pada tabel 3.

Tabel 3. Profil Kebutuhan Khusus Anak Responden

\begin{tabular}{|c|c|c|c|c|c|c|}
\hline & \multicolumn{6}{|c|}{ Jenis kelamin anak } \\
\hline & \multicolumn{4}{|c|}{ Perempuan } & \multicolumn{2}{|c|}{ Laki-laki } \\
\hline$\sum$ & \multicolumn{4}{|c|}{13} & \multicolumn{2}{|c|}{23} \\
\hline$\%$ & \multicolumn{3}{|c|}{$(36,1 \%)$} & & \multicolumn{2}{|c|}{$(63,9 \%)$} \\
\hline & \multicolumn{6}{|c|}{ Jenis kebutuhan khusus } \\
\hline \multirow{4}{*}{$\begin{array}{l}\sum \\
\%\end{array}$} & Tunarungu & Tunagrahita & Autis & ADHD & Kesulitan belajar & Lamban belajar \\
\hline & 12 & 12 & 4 & $5(13,9 \%)$ & 2 & 1 \\
\hline & $(33.3 \%)$ & $(33,3 \%)$ & $(11,1 \%)$ & & $(5,6 \%)$ & $(2,8 \%)$ \\
\hline & \multicolumn{6}{|c|}{ Usia anak } \\
\hline & \multicolumn{2}{|c|}{$7-10$ tahun } & \multicolumn{2}{|r|}{ 11-14 tahun } & $15-18$ & $19-22$ \\
\hline$\sum$ & \multicolumn{2}{|c|}{20} & \multicolumn{2}{|r|}{10} & 5 & 1 \\
\hline$\overline{\%}$ & \multicolumn{4}{|c|}{$(27,8 \%)$} & $(13,9 \%)$ & $(2,8 \%)$ \\
\hline & \multicolumn{6}{|c|}{ Penempatan anak } \\
\hline & \multicolumn{5}{|c|}{ Sekolah luar biasa (SLB)/ sekolah khusus } & Sekolah inklusi \\
\hline$\sum$ & \multicolumn{4}{|c|}{31} & \multicolumn{2}{|r|}{5} \\
\hline$\%$ & \multicolumn{4}{|c|}{$(86,1 \%)$} & \multicolumn{2}{|r|}{$(13,9 \%)$} \\
\hline
\end{tabular}

\section{Profil Responden Guru}

Berdasarkan data yang masuk selama waktu pengisian survei terdapat 58 responden yang mengisi survei. Peran responden di sekolah dapat dilihat pada Tabel 4.

Tabel 4. Peran responden di sekolah

\begin{tabular}{lrr}
\hline Peran di sekolah & \multicolumn{1}{c}{$\sum$} & \multicolumn{1}{c}{$\%$} \\
\hline Guru BK di SLB & 1 & $2 \%$ \\
Guru kelas di SLB & 42 & $72 \%$ \\
Guru mata pelajaran di SLB & 1 & $2 \%$ \\
Guru Pembimbing Khusus & 6 & $10 \%$ \\
Kepala sekolah SLB & 4 & $7 \%$ \\
Kepala sekolah inklusi & 2 & $3 \%$ \\
Guru TKLB & 1 & $2 \%$ \\
Terapis sekolah & 1 & $2 \%$ \\
\hline
\end{tabular}


Mayoritas responden merupakan guru kelas di SLB, yaitu sebanyak 72\%. Sejalan dengan persebaran asal responden orangtua, asal responden guru pun berasal dari Bandar Lampung sebanyak 48\%, diusul Kota Metro sebanyak 29\%. Persebaran daerah yang tidak merata dimungkinkan berpengaruh pada keanekaragaman jawaban yang diberikan. Beberapa guru mengajar lebih dari satu kekhususan, seperti responden yang mengajar tunagrahita dan autis dalam satu kelas. Data keanekaragaman jenis kebutuhan khusus siswa yang diajarkan dapat dilihat pada Grafik 1.

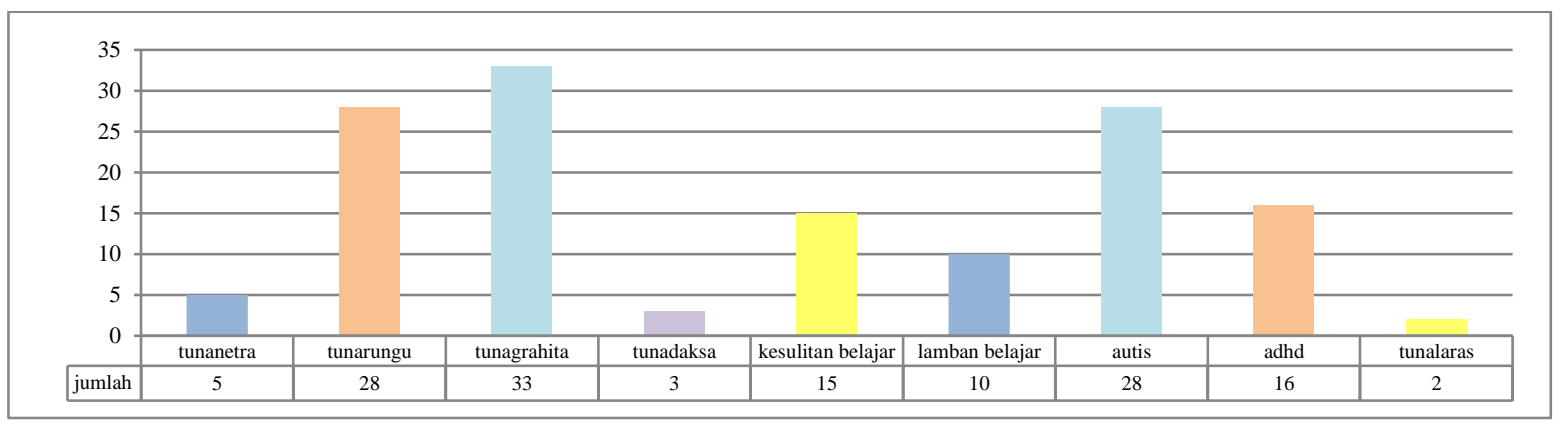

Grafik 1. Jenis kebutuhan khusus yang diajar

Tak hanya asal daerah, jenis kekhususan siswa yang diajarkan pun beragam. Responden menjawab apakah jenis kebutuhan khusus yang dimiliki siswa.Jenis kebutuhan khusus yang paling banyak diagar oleh responden adalah tunagrahita, yaitu sebanyak 33 responden. Usia responden juga beragam yang dapat dilihat pada Grafik 2 .

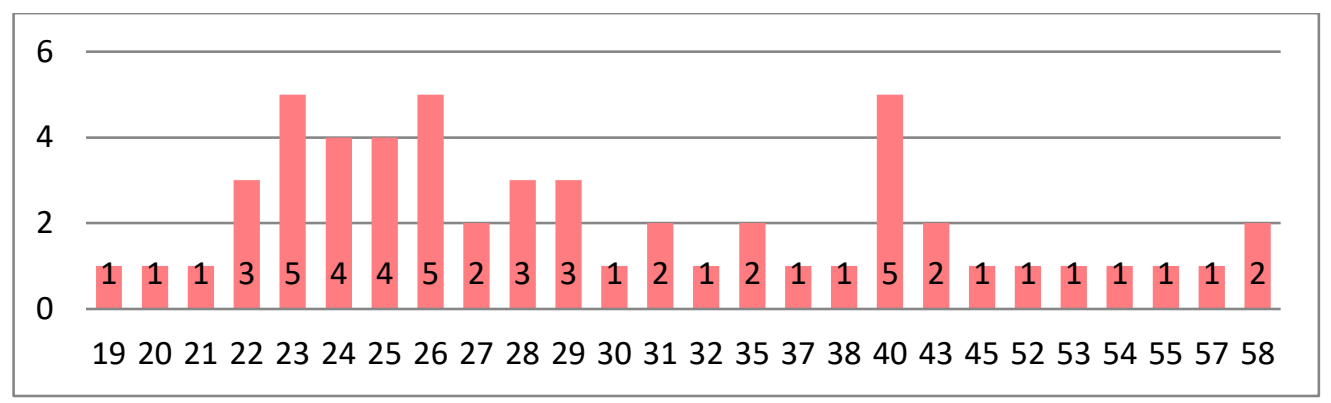

\section{Grafik 2. Usia Responden}

Menurut Grafik 2, usia reponden didominasi pada guru usia 22-30 tahun. Usia responden yang termuda adalah 19 tahun dengan yang tertua berusia 58 tahun. Selain usia yang beragam, Tabel 5 menampilkan latar belakang pendidikan responden.

Tabel 5. Latar Belakang Pendidikan Responden Guru

\begin{tabular}{lrr}
\hline Latar Belakang Pendidikan & $\Sigma$ & $\%$ \\
\hline Bimbingan Dan Konseling & 3 & $5 \%$ \\
Biologi & 2 & $3 \%$ \\
Ekonomi Koperasi & 1 & $2 \%$ \\
Fisika Murni & 1 & $2 \%$ \\
Fisioterapi & 1 & $2 \%$ \\
Ilmu Komputer & 3 & $5 \%$ \\
Manajemen Informatika & 1 & $2 \%$ \\
Pendidikan Agama & 1 & $2 \%$ \\
Pendidikan Bahasa Inggris & 3 & $5 \%$ \\
Pendidikan Luar Biasa/Pendidikan Khusus & 27 & $47 \%$ \\
Pendidikan Matematika & 1 & $2 \%$ \\
PGSD & 4 & $7 \%$ \\
Psikologi & 3 & $5 \%$ \\
SMA/SMK & 5 & $9 \%$ \\
Teknologi Pendidikan & 1 & $2 \%$ \\
Terapi Okupasi & 1 & $2 \%$ \\
\hline
\end{tabular}


Sebanyak 27 (47\%) guru berlatar belakang jurusan Pendidikan Luar Biasa/Pendidikan Khusus. Sedangkan sisanya, sebanyak $31(53 \%)$ berlatar belakang jurusan lain. Selanjutnya, pertanyaan mengenai apakah guru yang berlatar belakang jurusan lain pernah mengikuti pelatihan atau tidak. Sebanyak 14 guru dari 31 guru yang berlatar belakang selain pendidikan khusus mengaku pernah mendapatkan pelatihan pembelajaran anak berkebutuhan khusus. Meskipun pelatihan tersebut tidak spesifik berbentuk pembelajaran bagi anak berkebutuhan khusus melainkan pendidikan secara umum atau bersifat keterampilan. Selain itu, 2 responden yang berasal dari jurusan lain menyebutkan bahwa mereka tengah menempuh pendidikan kembali di jurusan Pendidikan Luar Biasa.

\section{Hasil Survei Pelaksanaan PJJ terhadap Orangtua}

\section{Aktivitas orangtua selama Pandemi}

Berdasarkan jawaban responden, diketahui bahwa 18 (50\%) responden bekerja di rumah selama pandemi Covid-19, dan 18 (50\%) responden lain tetap bekerja selama pandemi. Sehingga dapat dikatakan bahwa orangtua yang bekerja dari rumah dan tetap bekerja di luar sama besarnya. Selanjutnya, 15 responden menjawab bahwa kedua orangtua bekerja dari rumah, 19 menjawab hanya salah satu yang bekerja dari rumah, dan 2 responden menyebutkan kedua orangtua tetap bekerja dari luar.

Gambar 1 menunjukkan tentang aktivitas kerja orangtua. Dari gambar tersebut dapat dilihat bahwa $42 \%$ kedua orangtua bekerja dari rumah dan 53\% salah satu bekerja dari rumah. Hal ini mengindikasikan bahwa adanya orangtua anak berkebutuhan khusus di rumah saat PJJ diterapkan. Meskipun, orangtua tetap melakukan aktivitas pekerjaan di rumah.

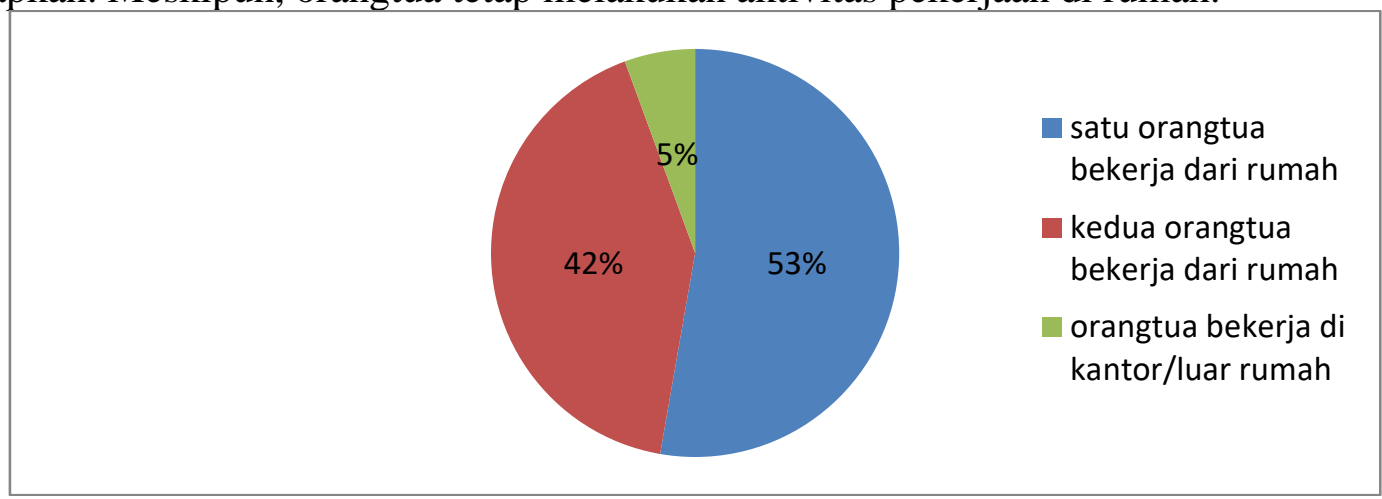

Gambar 1. Aktivitas Kerja Orangtua di Masa Pandemi

\section{Pelaksanaan PJJ}

Seluruh responden sebanyak 36 orangtua, menyebutkan bahwa anak mereka mendapatkan pembelajaran jarak jauh melalui daring dari sekolah. Berkenaan dengan penjadwalan dan waktu dalam sekali pertemuan dapat dilihat pada Tabel 6 berikut.

Tabel 6. Jadwal Pertemuan Perminggu

\begin{tabular}{llr}
\hline Jumlah pertemuan dalam seminggu & $\sum$ & $\%$ \\
\hline 1 kali & 1 & $3 \%$ \\
2 kali & 2 & $6 \%$ \\
3 kali & 6 & $17 \%$ \\
4 kali & 5 & $14 \%$ \\
5 kali & 15 & $42 \%$ \\
6 kali & 7 & $19 \%$ \\
\hline
\end{tabular}

Berdasarkan Tabel 6, diketahui bahwa jumlah pertemuan paling banyak adalah sebanyak lima kali dalam seminggu, yaitu sebanyak $41,7 \%$. Beberapa responden menambahkan bahwa pertemuan dilakukan dari Senin hingga Jumat. Sebanyak 7 responden $(19,4 \%)$ menjawab pertemuan dilakukan Senin hingga Sabtu. 


\section{JPK (Jurnal PendidikanKhusus), 16 (2), 2020 - 54}

Ossy Firstanti Wardany, Yulvia Sani

Terdapat satu responden yang menjawab pembelajaran hanya dilakukan selama satu kali dalam seminggu. Responden tersebut kemudian menjelaskan bahwa durasi belajar selama satu kali pertemuan adalah satu jam. Tabel 8 berikut menampilkan data berkenaan dengan durasi tiap pertemuan.Hasil menunjukkan bahwa separuh dari responden atau 58,3 \% menyebutkan bahwa durasi belajar bersama guru dalam satu kali pertemu berlangsung selama 1 jam. Durasi terlama adalah selama empat jam dalam satu pertemuan dan dijawab oleh satu orang responden. Durasi tersingkat aadalah tiga puluh menit pada satu kali pertemuan yang juga dijawab oleh seorang responden. Dapat disimpulkan bahwa terdapat keragaman baik dari jumlah pertemuan maupun durasi tiap pertemuan. Hal ini dimungkinkan terjadi karena perbedaan kebijakan tiap sekolah atau guru, dan keadaan anak dan tersedianya waktu orangtua dalam mendampingi anak.

Tabel 7. Durasi Tiap Pertemuan

\begin{tabular}{llr}
\hline Durasi tiap pertemuan & $\sum$ & $\%$ \\
\hline 1 jam & 21 & $58 \%$ \\
2 jam & 10 & $28 \%$ \\
3 jam & 3 & $8 \%$ \\
4 jam & 1 & $3 \%$ \\
30 menit & 1 & $3 \%$ \\
\hline
\end{tabular}

Selain durasi dan jumlah pertemuan, aplikasi atau platform yang digunakan untuk belajar pun berbeda-beda. Meskipun menurut jawaban responden, aplikasi yang dipakai orangtua untuk terhubung dengan guru cenderung didominasi dengan aplikaci pesan Whatsapp. Berkaitan aplikasi yang digunakan dengan orangtua dapat dilihat pada Grafik 3 berikut.

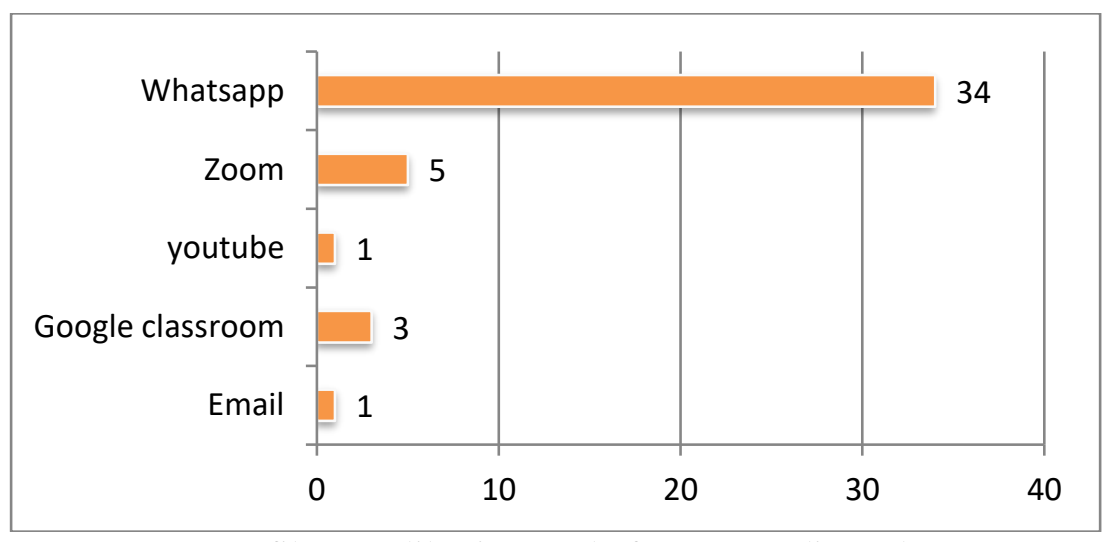

Grafik 3. Aplikasi atau platform yang digunakan

Grafik 3 menunjukkan bahwa Youtube dan Email merupakan aplikasi yang sangat jarang digunakan oleh orangtua dan guru dalam belajar. Penggunaan aplikasi video conference melalui Zoom digunakan oleh lima orang responden untuk melaksanan pertemuan dan pembelajaran anak berkebutuhan khusus secara tatap muka virtual. Zoom digunakan oleh 3 responden dengan anak dengan spektrum autis, dan 2 dengan anak ADHD, ketiganya diketahui bersekolah di sekolah inklusi. Terdapat 3 responden yang menggunakan platform kelas daring seperti Google classroom. Ketiga responden yang menggunakan google classroom terdiri atas dua orang tunarungu dan seorang autis di kabupaten yang berbeda.

Tidak hanya aplikasi atau pun platform yang digunakan oleh guru dan orangtua, peneliti juga menanyakan perihal metode apa yang sering digunakan oleh guru. Grafik 4 menunjukkan bahwa metode pembelajaran didominasi membagikan materi serta penugasan secara rutin. Selain itu, sebanyak 21 responden menjawab bahwa guru aktif membagikan pembelajaran dengan mengirimkan atau mengunggah video pembelajaran, dan sebanyak 5 orang menjawab melalui rekaman suara. Hal ini menunjukkan bahwa guru tidak hanya membagikan tugas atau pun materi berbentuk dokumen atau gambar. Beberapa guru mengunggah video pembelajaran dan rekaman suara mereka. Meskipun tidak banyak, terdapat 4 responden yang menyebutkan penggunaan video conference sebagai metode 
berkomunikasi secara interaktif antara guru dan siswa. Hal ini sejalan dengan penggunaan Zoom yang disebutkan pada aplikasi yang digunakan sebelumnya. berikut.

Responden dapat memilih lebih dari satu jawaban dan hasil survei dapat dilihat pada Grafik 4

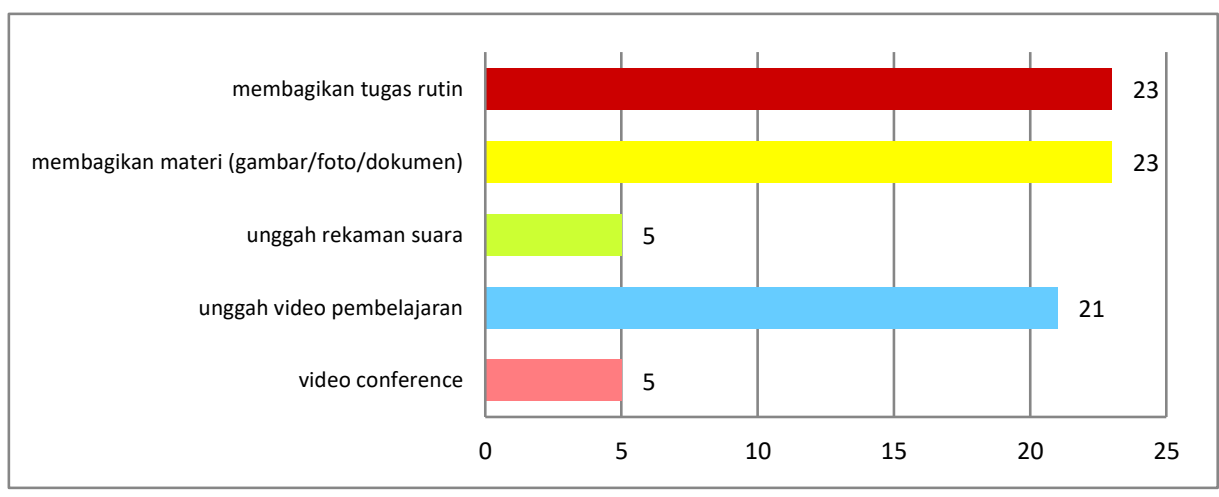

Grafik 4. Metode Guru Menyampaikan Materi pada Anak dan Orangtua

Beberapa responden menjelaskan dengan detail apa yang dipelajari anaknya. Responden nomor 29 dengan anak autis berusia 11 tahun misalnya, ia menjelaskan bahwa pembelajaran berbentuk menggambar, mewarnai, menebalkan huruf, hapalan lagu wajib nasional, senam ABK, dan brain gym. Selain itu, terdapat jawaban penggunaan bahasa isyarat sesuai materi yang disampaikan melalui video. Seperti pada Responden 7 dengan anak tunarungu yang mengemukakan anaknya menerima pembelajaran membaca dan menghitung dengan isyarat melalui whatsapp. Guru mengirimkan materi dalam bentuk file, gambar dan video pembelajaran untuk diikuti anak di rumah.

Materi pembelajaran pun tidak hanya akademik, tetapi bina diri pun dilakukan. Contoh jawaban responden nomor 26 dengan anak tunagrahita yang menyebutkan bahwa materi pembelajaran adalah kegiatan anak sehari-hari di rumah, seperti belajar menyapu. Responden nomor 25 dengan anak autis menyebutkan bahwa anak juga mendapatkan pembelajaran sensori integrasi yang dipandu guru melalui Whatsapp. Hal ini berarti sebagian guru masih memberikan pembelajaran yang mengacu pada perkembangan anak dan tidak hanya akademik saja.

\section{Pengalaman orangtua dalam mendampingi PJJ}

Grafik 5 menunjukkan bahwa 19\% anak didampingi ayah, 89\% didampingi Ibu, 3\% didampingi nenek, dan 14\% didampingi saudara kandung. Persentasi tersebut merupakan persentasi campuran. Hal ini disebabkan karena adanya kolaborasi ataupun pendampingan secara bergantian. Sebanyak 2 responden menjawab bahwa tugas mendampingi anak berkebuhan khusus secara bergantian dilakukan oleh ayah, ibu, atau saudara kandung. 1 responden mengemukakan bahwa pendampingan dilakukan oleh Ibu atau nenek. 5 responden menjawab secara bergantian ayah dan ibu yang mendampingi belajar dan 1 responden menjawab ibu atau kakak yang mendampingi.

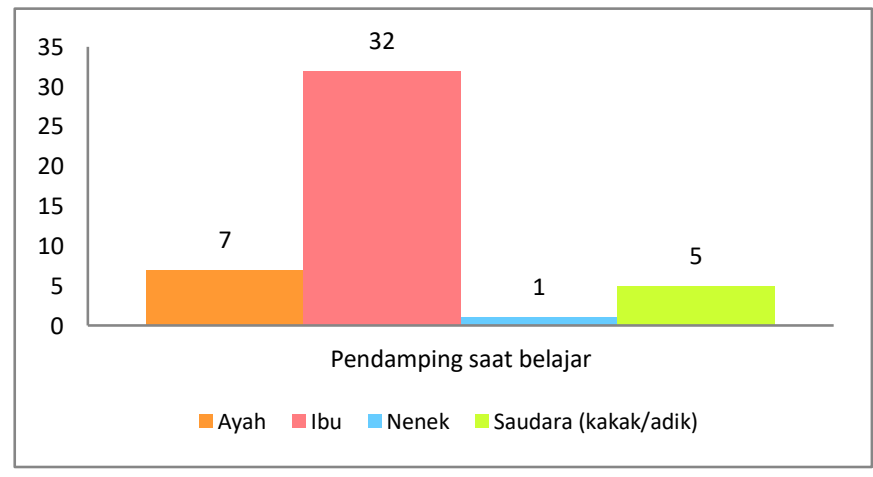

Grafik 5. Pendamping Saat Belajar 


\section{JPK (Jurnal PendidikanKhusus), 16 (2), 2020 - 56}

Ossy Firstanti Wardany, Yulvia Sani

Terkait pengalaman mendampingi pembelajaran daring, Tabel 9 menyebutkan bahwa mengunggah materi berupa gambar, foto atau dokumen adalah jenis metode yang paling disukai responden orangtua. Hal ini dapat terlihat dari presntase sebanyak $53 \%$ orangtua memilih opsi tersebut. Video conference menjadi metode yang paling sedikit dipilih. Video conference menjadi metode pembelajaran yang paling sedikit dipilih. Pemilihan video conference yang sedikit sejalan dengan penggunaannya yang hanya digunakan oleh 5 responden. Kurangnya pengalaman dalam penggunaan dapat menjadi alasan responden dalam memilih metode yang disukai.

Tabel 8. Metode Pembelajaran Yang Disukai Orangtua

\begin{tabular}{lll}
\hline Metode pembelajaran yang disukai & $\sum$ & $\%$ \\
\hline mengunggah materi (gambar/foto/dokumen) & 19 & $53 \%$ \\
Memberikan tugas secara rutin & 9 & $25 \%$ \\
mengunggah video pembelajaran & 6 & $17 \%$ \\
Semua pembelajaran saya suka & 1 & $3 \%$ \\
Video conference & 1 & $3 \%$ \\
\hline
\end{tabular}

Berdasarkan Tabel 8, pemilihan mengunggah materi sebagai yang paling disukai ternyata tidak hanya karena pengunaan metode tersebut yang terbanyak digunakan. Akan tetapi, terdapat sejumlah alasan yang diberikan responden terkait metode yang disukai yang dapat dilihat pada Tabel 10.

Tabel 9. Alasan Menyukai Metode Tertentu

\begin{tabular}{ll}
\hline Metode pembelajaran yang disukai & Alasan \\
\hline \multirow{2}{*}{$\begin{array}{l}\text { Mengunggah materi } \\
\text { gambar/foto/dokumen) }\end{array}$} & - Mudah diterima dan dilaksanakan \\
& - Efisien waktu dan lebih mudah bagi orangtua yang kurang \\
& menguasai internet \\
Memberikan tugas secara rutin & - Audah dipahami orangtua untuk dijelaskan ke anak \\
& - Bisa mengetahui sejauh mana perkembangan belajar anak \\
Mengunggah video pembelajaran & - Karena anak senang ketika belajar dengan melihat gambar dan \\
& contoh pada video \\
Semua pembelajaran saya suka & - Anak lebih memahami karena guru menjelaskan dengan video \\
Video conference & - Karena yakin semua berguna \\
\hline
\end{tabular}

Merujuk pada Tabel 9 mengunggah materi paling banyak dipilih responden karena mudah untuk diterima, efisien dan menghemat waktu, orangtua dapat dengan mudah menjelaskan ke anak. Selain itu alasan seperti orang tua lebih mudah mengakses sebab kurang menguasai internet juga menjadi faktor utama. Kurangnya penguasaan internet pada orangtua ternyata berpengaruh terhadap metode pembelajaran yang digunakan dan disukai.

\section{Kendala dan Permasalahan dalam mendampingi anak berkebutuhan khusus}

Berdasarkan pertanyaan adakah kendala atau permasalahan selama mendampingi anak berkebutuhan khusus belajar sebanyak 27 responden atau $75 \%$ dari sampel penelitian menyebutkan bahwa mereka terkendala. Sebanyak 19\% tidak terkendala dan $6 \%$ merasa ragu-ragu apakah mereka terkendala atau tidak. Responden yang menjawab "ya" pada pertanyaan adanya permasalahan selama mendampingi anak berkebutuhan khusus belajar kemudian menuliskan kendala yang mereka alami. Beberapa orangtua memiliki dua atau lebih kendala dalam pelaksanaan pembelajaran.

Kendala yang paling sering dialami oleh orangtua adalah kondisi anak yang kadang kurang siap untuk menerima pembelajaran. Sebanyak 39\% orangtua mengaku bahwa terkadang mengalami kesulitan ketika anak jenuh, bosan, sulit fokus dan mood yang berubah-ubah. Selain permasalahan anak, permasalahan jaringan dan kuota internet ternyata menjadi kendala dalam mendampingi anak. Sebanyak $14 \%$ responden mengaku sering terkendala dengan jaringan internet. Seorang responden mengaku sering tiba-tiba kehabisan kuota internet saat pembelajaran sedang berlangsung. Sedangkan beberapa responden lain mengaku seringkali mengalami kesulitan mengakses materi karena ketidakstabilan sinyal. Secara lengkap kendala tersebut dapat dilihat pada Tabel 11. 
JPK (Jurnal PendidikanKhusus), 16 (2), 2020 - 57

Ossy Firstanti Wardany, Yulvia Sani

Tabel 10. Kendala Saat Mendampingi Anak

\begin{tabular}{lll}
\hline Kendala saat mendampingi anak & $\sum$ & $\%$ \\
\hline Kuota dan jaringan internet & 5 & $14 \%$ \\
Orangtua bekerja dan sulit membagi waktu & 2 & $6 \%$ \\
Anak jenuh, bosan, mood berubah, sulit fokus & 14 & $39 \%$ \\
Sulit menguasai materi anak & 2 & $6 \%$ \\
Kurang memahami cara & 4 & $11 \%$ \\
membimbing/mendampingi anak & 4 & $11 \%$ \\
Kurang sabar dalam mendampingi anak & 2 & $6 \%$ \\
Anak belum dapat menguasai internet seperti email & 1 & $3 \%$ \\
Situasi rumah tidak kondusif untuk anak belajar & 1 & $6 \%$ \\
Gawai untuk belajar digunakan untuk bermain & 2 & \\
\hline
\end{tabular}

Masalah lain yang juga banyak terjadi menyangkut keadaan orangtua yang belum memahami cara mendampingi anak. Sebanyak $11 \%$ responden mengatakan belum memahami bagaimana mengajarkan anak berkebutuhan khusus di rumah. Sama besar, $11 \%$ responden orangtua pun menyebutkan bahwa mereka merasa kurang sabar dalam mendampingi anak. Masalah-masalah lain terkait situasi dan kondisi di rumah pun dialami responden orangtua. Sehingga dapat dikatakan bahwa meskipun pembelajaran jarak jauh berjalan dengan cukup baik, akan tetapi kendala terkait teknis, situasi, kondisi, dan cara menangani dari orangtua kerap terjadi.

\section{Aktivitas lain dari orangtua kepada anak saat di rumah}

Adanya kebijakan bekerja dari rumah pada sebagian orangtua barang tentu berimplikasi pada kuantitas waktu yang dimiliki orangtua dan anak selama di rumah. Pertanyaan selanjutnya berkenaan dengan apakah orangtua memfasilitasi kegiatan lain di rumah selain belajar. Hasilnya menyebutkan bahwa sebanyak 32 orangtua atau $89 \%$ dari sampel orangtua menjawab mereka memfasilitasi kegiatan lain.Selanjutnya berkenaan dengan aktivitas lain yang diberikan orangtua dapat dilihat pada Tabel. Responden dapat memilih lebih dari satu aktivitas.

Tabel 11. Aktivitas Yang Dilakukan Orangtua Dan Anak Selain Belajar

\begin{tabular}{llr}
\hline \multicolumn{1}{c}{ Aktivitas yang dilakukan } & $\sum$ & $\%$ \\
\hline Mengakses aplikasi pembelajaran daring (Rumah belajar, ruangguru, Zenius, & 2 & $6 \%$ \\
kelas pintar,dsb) & 9 & $25 \%$ \\
Menonton program "Belajar dari Rumah" di TVRI & 24 & $67 \%$ \\
Melatih bina diri (mencuci piring, menyapu, memakai pakaian, memasak) & 8 & $22 \%$ \\
Membaca buku & 11 & $31 \%$ \\
Menonton video pembelajaran di youtube & 23 & $64 \%$ \\
Membuat prakarya, mewarnai, berkebun dan kegiatan rekrasi lain & 1 & $3 \%$ \\
mengaji & 1 \\
\hline
\end{tabular}

\section{Harapan dan saran dari orangtua}

Sebagian besar orangtua menuliskan harapan agar pandemi Covid-19 bisa segera berakhir dan anak-anak dapat kembali ke sekolah. Orangtua berharap guru tetap bersemangat dan rutin mengajar daring anak mereka. Berkenaan saran dan masukan dari orangtua selengkapnya pada Tabel 13.

Tabel 12. Harapan dan Saran dari Orangtua

\begin{tabular}{ll}
\hline Harapan & Saran \\
\hline Covid-19 segera berakhir & Guru dapat memberikan contoh video pelaksanaan terapi \\
$\begin{array}{l}\text { Anak bisa segera kembali ke sekolah } \\
\text { Guru tetap semangat }\end{array}$ & $\begin{array}{l}\text { Guru bisa lebih telaten dan sabar } \\
\text { guru tetap rutin mengajar daring dan } \\
\text { berkomunikasi dengan anak }\end{array}$ \\
& Waktu pengiriman tugas tidak dibatasi \\
& $\begin{array}{l}\text { Guru bisa bertemu anak meski seminggu sekali atau dua } \\
\text { minggu sekali agar anak }\end{array}$ \\
\hline
\end{tabular}




\section{Hasil Survei terhadap Guru}

\section{Adanya PJJ selama pandemi dan sosialisasi PJJ}

Hasil survei pada 58 guru menyebutkan bahwa sekolah tempat mereka mengajar mengubah pembelajaran menjadi belajar di rumah. Selanjutnya, keseluruhan guru atau sebanyak $98 \%$ guru mengaku bahwa pembelajaran dilaksanakan melalui daring, dan seorang guru (2\%) tidak melaksanakan pembelajaran daring melainkan home visit (mengunjungi siswa). Selanjutnya $91 \%$ guru menyebutkan adanya sosialisasi PJJ sebelum pembelajaran dilakukan. Berdasarkan pertanyaan apa peran guru dalam proses sosialisasi, 45 guru (78\%) menyebutkan bahwa mereka turut berperan dalam proses sosialisasi, sedangkan sisanya sebanyak 8 guru tidak menjawab. Adapun peran yang dimaksud seperti menjadi fasilitator, informan dari sekolah ke orangtua terkait adanya sosialisasi, pemateri sosialisasi, hingga sebagai tutor orangtua dalam penggunaan aplikasi pendukung belajar dari seperti bagaimana menggunakan Zoom dan Google Classroom. Hal ini menunjukkan bahwa hampir sebagian guru memperkenalkan dan memberikan pemahaman serta pembelajaran bagi orangtua terkait PJJ. Sosialisasi berperan besar dalam pelaksanaan PJJ. Seluruh guru yang sekolahnya mengadakan sosialisasi mengatakan bahwa kegiatan ini membantu komunikasi dan proses belajar anak di rumah.

\section{Mata pelajaran, Jadwal dan waktu belajar}

Responden didominasi oleh guru kelas, sehingga pada pertanyaan mata pelajaran apa yang diajarkan di sekolah sebelum Covid-19, sebanyak 78\% guru menyebutkan mereka mengajarkan semua pembelajaran atau tematik, kecuali Pendidikan Agama dan Olahraga. Sedangkan sisanya merupakan guru bidang studi seperti Matematika dan Bahasa Inggris, atau terapis dan konselor sekolah. Mata pelajaran yang diajarkan guru secara lengkap dapat dilihat pada Tabel. 13

Tabel 13. Mata Pelajaran Yang Diajarkan Guru

\begin{tabular}{lrr}
\hline Mata pelajaran yang diajarkan guru & \multicolumn{1}{c}{$\%$} \\
\hline Tematik/semua mata pelajaran kecuali agama dan olahraga & 45 & $78 \%$ \\
Bahasa Inggris & 2 & $3 \%$ \\
Terapi perilaku, terapi wicara, sensori integrasi & 3 & $5 \%$ \\
Matematika & 2 & $3 \%$ \\
Bimbingan konseling & 2 & $3 \%$ \\
Bina diri & 2 & $3 \%$ \\
Olahraga & 2 & $3 \%$ \\
\hline
\end{tabular}

Hasil survei selanjutnya mendapati sebanyak $76 \%$ atau 44 guru memberikan semua pembelajaran lewat daring dalam PJJ. Sedangkan sisanya, sebanyak $24 \%$ atau 14 guru tidak mengajarkan seluruh mata pembelajaran saat PJJ daring. Ada pun pembelajaran yang tidak diajarkan selama pandemi oleh $24 \%$ guru tersebut adalah pembelajaran yang bersifat praktik seperti bina diri, tata boga, olahraga, Bina Persepsi Bunyi dan Irama (BPBI). Salah satu responden menyebutkan bahwa mereka tidak melaksanakan pembelajaran yang sulit apabila dilakukan oleh orangtua. Namun demikian, hampir seluruh responden menyebutkan bahwa pembelajaran mengikuti keadaan dan perkembangan serta kemampuan anak saat ini.

\section{Pelaksanaan dan pengalaman guru dalam PJJ}

Sebanyak 43 guru atau 74\% dari sampel menjawab melaksanakan PJJ sesuai dengan jadwal. Sisanya dengan persentase $26 \%$ atau 15 guru melaksanakan tidak sesuai jadwal. Waktu pelaksanaan PJJ tiap satu sesi atau satu mata pelajaran beragam. Sebanyak $31 \%$ atau 18 guru mengaku mereka tidak memiliki aturan jam khusus dalam belajar. Durasi tiap sesi bergantung pada keadaan dan kebutuhan anak. Selanjutnya $26 \%$ guru menyebutkan pembelajaran dilakukan selama satu jam atau $2 \times 30$ menit. Grafik 6 berisi durasi pelaksanaan satu jam pelajaran. 
JPK (Jurnal PendidikanKhusus), 16 (2), 2020 - 59

Ossy Firstanti Wardany, Yulvia Sani

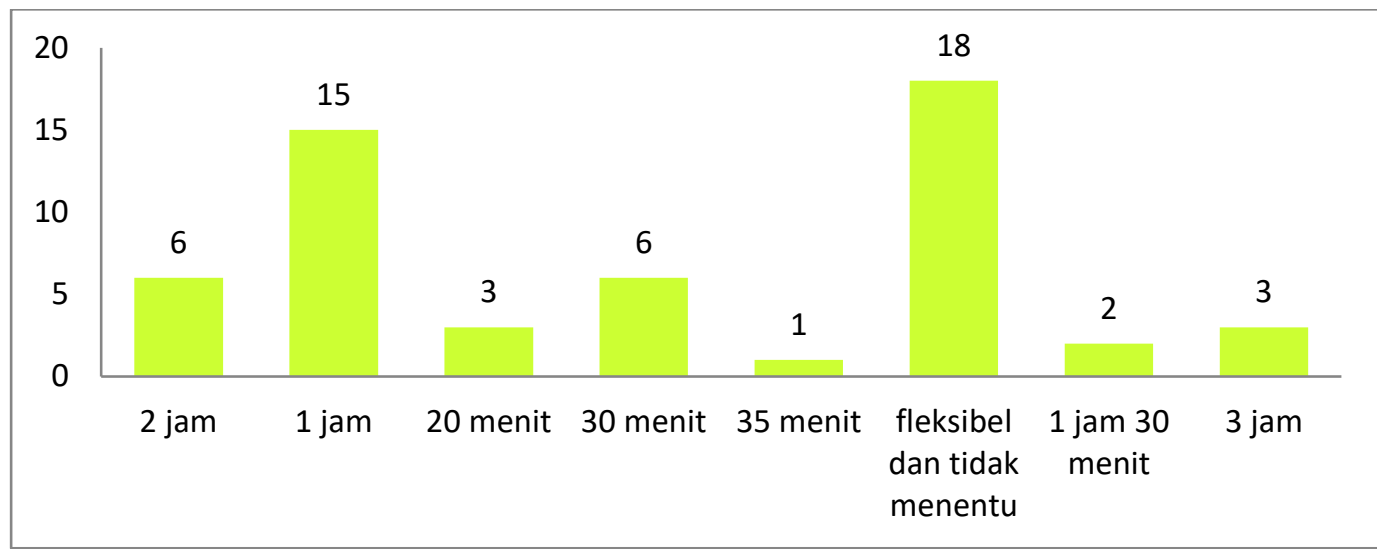

Grafik 6. Waktu Pelaksanaan PJJ Tiap Satu Sesi Atau Satu Mata Pelajaran

Selain waktu, hal terkait media yang digunakan oleh guru dan orangtua, dapat dilihat pada Tabel 14. Beberapa guru menyebutkan mereka menggunakan lebih dari satu media komunikasi dalam pelaksanaan PJJ.

Tabel 14. Media Komunikasi Yang Digunakan Guru

\begin{tabular}{lll}
\hline Media komunikasi yang digunakan & $\sum$ & $\%$ \\
\hline Email & 3 & $5 \%$ \\
Facebook & 3 & $5 \%$ \\
google classroom & 8 & $14 \%$ \\
google meet & 2 & $3 \%$ \\
Home visit & 3 & $5 \%$ \\
Instagram & 1 & $2 \%$ \\
Line & 1 & $2 \%$ \\
SMS dan telepon & 1 & $2 \%$ \\
Whatsapp & 52 & $90 \%$ \\
Youtube & 10 & $17 \%$ \\
\hline
\end{tabular}

Penggunaan pesan instan seperti Whatsapp mendominasi media komunikasi yang digunakan guru. Temuan ini sejalan dengan hasil penelitian terhadap orangtua. Selain itu, terdapat tiga guru yang menyebutkan bahwa selain menggunakan media komunikasi, mereka juga melakukan home visit, atau berkunjung ke rumah siswa untuk mengantarkan materi pembelajaran dalam kurun waktu tertentu. Terkait metode yang digunakan, dapat dilihat pada Grafik 6 berikut. Sebagian guru menyebutkan lebih dari satu metode yang digunakan dalam PJJ dengan anak berkebutuhan khusus. Akan tetapi, didapati kecenderungan bahwa guru mengkolaborasikan antara penyampaian materi dengan pemberian tugas secara rutin. Hal ini dapat dilihat dari sebanyak 57 atau $98 \%$ guru memilih memberikan tugas secara rutin, dan 49 atau $84 \%$ mengatakan memberikan materi berupa gambar/dokumen pada orangtua.

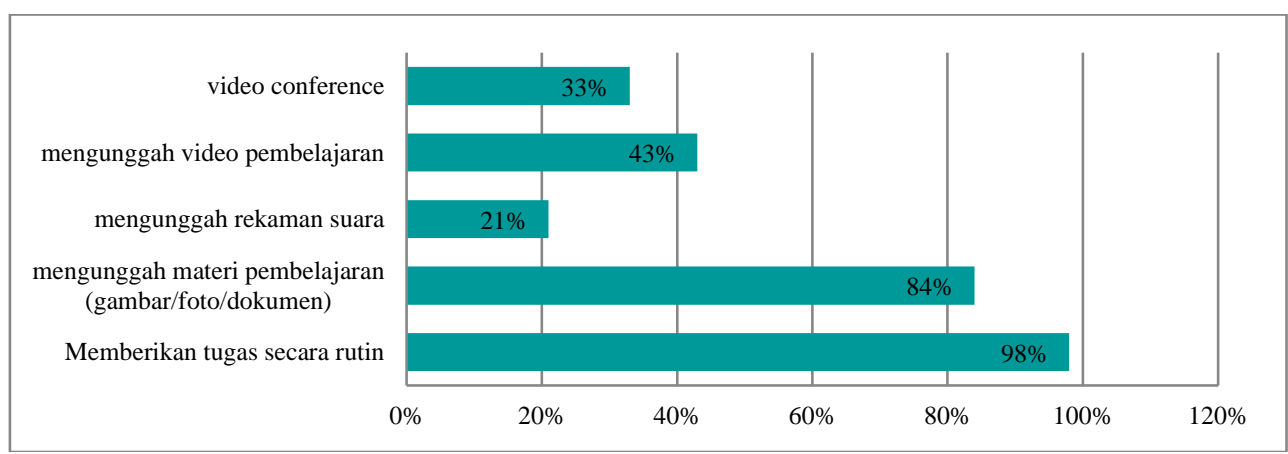

Grafik 7. Cara Guru Memberi Pembelajaran Pada Siswa Berkebutuhan Khusus 


\section{JPK (Jurnal PendidikanKhusus), 16 (2), 2020 - 60}

Ossy Firstanti Wardany, Yulvia Sani

Evaluasi pembelajaran jarak jauh dilakukan dengan berbagai cara. Bagaimana guru mengevaluasi siswa dapat dilihat pada Tabel 15 .

Tabel 15. Evaluasi Pembelajaran

\begin{tabular}{lll}
\hline Cara Evaluasi Pembelajaran & $\sum$ & $\%$ \\
\cline { 3 - 3 } \cline { 3 - 3 } evaluasi saat pembelajaran berlangung & 5 & $9 \%$ \\
keaktifan dan perilaku anak saat belajar & 2 & $3 \%$ \\
melakukan ulangan harian & 4 & $7 \%$ \\
membuat borang penilaian dan perkembangan yang diisi orangtua & 1 & $2 \%$ \\
menanyakan pada orangtua bagaimana perkembangan anak & 3 & $5 \%$ \\
Pengamatan kemajuan anak dari hari ke hari tiap tatap muka daring & 3 & $5 \%$ \\
Portofolio/hasil kerja yang diberikan kepada anak yang dianalisa perhari, perminggu & 37 & $64 \%$ \\
Post-tes setelah pembelajaran dilakukan (mengecek pemahaman anak, meminta anak & 3 & $5 \%$ \\
mengulangi) & 3 & \\
\hline
\end{tabular}

Hasil menunjukkan bahwa 64\% guru melakukan evaluasi berdasarkan hasil kerja siswa. Hal ini sejalan dengan temuan sebelumnya yang menunjukkan bahwa sebagian besar guru memberikan tugas setelah pemberian materi dilakukan Penggunaan media dan cara mengajar yang berubah tentu membutuhkan adaptasi. Terdapat 31\% (18 guru) yang menyatakan bahwa mereka mengalami kesulitan dalam mengakses media daring untuk pembelajaran, 64\% (37 guru) mengaku tidak mengalami kesulitan, dan 5\% (3 guru) mejawab ragu-ragu terkait kesulitan mengakses media. Guru mengaku tidak semua mata pelajaran dapat dengan mudah dilaksanakan secara daring. Selanjutnya Tabel menunjukkan mengenai mata pelajaran yang menurut guru sulit dilaksanakan secara daring.

Tabel 16. Pembelajaran Yang Sulit Dilaksanakan Daring Menurut Guru

\begin{tabular}{ll}
\hline Mata pelajaran & Alasan \\
\hline Olahraga & - Orangtua tidak selalu ada untuk mendampingi \\
& - Musik yang didengar anak berbeda dengan yang didengar guru \\
& membutuhkan tempat yang luas \\
& - Beberapa anak tidak mood tiap olahraga secara daring \\
Agama & - Kesulitan menuntun anak membaca tulisan arab dari jauh \\
& - Sulit mengajarkan membaca dari jauh \\
& - Perbedaan gaya mengajarkan membaca antara guru dan orangtua \\
& - Beberapa orangtua berekspektasi terlalu tinggi pada anak dalam \\
Bahasa indonesia & membaca yang seringkali berpengaruh pada emosi anak \\
& - Sulit memberikan contoh dan mengarahkan anak jika tidak secara \\
Terapi (sensori integrasi, terapi & langsung \\
wicara, terapi perilaku, dan & Orangtua yang terbatas dalam memahami anak dan seluk beluk \\
terapi lain) & terapi sehingga sulit ketika terapis mengarahkan orangtua \\
& Tidak semua orangtua selalu mendampingi anak dan memfasilitasi \\
Tata boga, komputer, musik, & anak dalam beberapa keterampilan vokasional yang diajarkan di \\
dan pembelajaran vokasional & sekolah
\end{tabular}

\section{Program Edukasi Parenting dan Covid-19 untuk orangtua}

Seperti yang disebutkan pada latar belakang bahwa adalah hal yang penting bagi orangtua untuk menguasai pengasuhan dan cara membimbing anak di rumah. Kurangnya penguasaan manajemen perilaku dan kesiapan belajar anak tentu menimbulkan masalah. Hal tersebut ditunjukkan dengan hasil survei yang menemukan bahwa tingkat orangtua mengeluh kesulitan dalam mendampingi anak kepada guru sangatlah tinggi. Hanya 3 guru atau 5\% dari total responden yang tidak pernah mendengar keluhan dari orangtua terkait anakm sedangkan 95\% pernah mendengar keluhan.Bedasarkan keluhan tersebut, guru menyebutkan mereka berupaya untuk mendampingi orangtua dalam mengasuh dan mendidik anak di rumah. Sebagaimana penggunaan aplikasi pesan instan paling banyak digunakan guru dalam pembelajaran, demikian pula cara guru mendampingi orangtua. Komunikasi terkait keluhan orangtua 


\section{JPK (Jurnal PendidikanKhusus), 16 (2), 2020 - 61}

Ossy Firstanti Wardany, Yulvia Sani

dan solusi yang diberikan guru 78\% dilakukan via konsultasi chat. Tabel 17 menunjukkan bahwa guru berusaha mendampingi dan membantu orangtua dalam mengoptimalkan perkembangan anak.

Tabel 17. Cara guru menanggapi keluhan dan kesulitan orangtua

\begin{tabular}{lrr}
\hline Cara guru mendampingi orangtua menghadapi kesulitan & $\sum$ & $31 \%$ \\
\hline Home visit & 18 & $78 \%$ \\
Konsultasi chat & 45 & $75 \%$ \\
Konsultasi video conference & 15 & $26 \%$ \\
Konsultasi melalui telepon & 19 & $33 \%$ \\
Menanyakan kesulitan setiap sesi pembelajaran dan memberikan solusi langsung & 1 & $2 \%$ \\
\hline
\end{tabular}

Hal lain, sebanyak 36\% guru mengaku memberikan pelatihan parenting bagi orangtua. Guru yang menjawab "ya" mengatakan bahwa program parenting ini dilakukan melalui diskusi di grup chat orangtua, melakukan pemberian materi parenting via video conference dari sekolah, membuka konsultasi personal, dan mengajak orangtua mengikuti Webinar, baik yang diselenggarakan oleh sekolah maupun dari luar. Tidak hanya mengenai program parenting, sejumlah 39 guru (67\%) mengaku memberikan edukasi terkait Covid-19 kepada guru dan orangtua. Pemberian edukasi tersebut dilakukan melalui berbagai cara yang terangkum pada Tabel 18 berikut.

Tabel 18. Cara Sekolah Dan Guru Mengedukasi Pencegahan Covid-19

\begin{aligned} & \hline No. Cara mengedukasi orangtua dan anak berkebutuhan khusus \\ & \hline 1 Sosialisasi daring dari sekolah oleh guru kepada anak dan orangtua \\ & 2 Memberikan video, gambar, dan bacaan tentang Covid-19 \\ & 3 Membuat sendiri video edukasi tentang pencegahan Covid-19 \\ & 4 Bekerja sama dengan orangtua dalam membuat prgram PHBS bagi anak di rumah \\ & 5 Memanggil dokter untuk sosialisasi daring \\ & 6 Memberikan pembaharuan informasi secara berkala \\ & 7 Bekerja sama dengan ambulance keliling memberikan anjuran kesehatan \\ & 8 Memasukkan isu Covid-19 dalam pembelajaran \\ & 9 Memberikan tugas membuat poster/gambar bagi anak terkait Covid-19 \\ & \hline\end{aligned}

\section{Kendala dan saran}

Berkaitan dengan pertanyaan mengenai adakah kendala dalam pembelajaran daring selama PJJ, $84 \%$ guru menjawab ada, dan sisanya $16 \%$ menjawab tidak ada. Kendala guru dalam memberikan pembelajaran disajikan pada Tabel. Beberapa guru memiliki masalah yang tidak hanya satu dalam pelaksanaan.

Tabel 19. Kendala Guru Mengajar Daring

\begin{tabular}{|c|c|c|}
\hline Kendala mengajar daring & $\sum$ & $\%$ \\
\hline Keterlibatan orangtua yang bekerja hingga sore/malam sehingga tidak ada yang mendampingi & 12 & $21 \%$ \\
\hline Kesulitan orangtua mengakses penggunaan media daring dan membuka materi digital & 5 & $9 \%$ \\
\hline Keadaan anak (mood berubah, tidak mau belajar daring) & 20 & $34 \%$ \\
\hline jaringan dan sinyal yang tidak stabil & 25 & $43 \%$ \\
\hline tidak semua orangtua memiliki alat komunikasi yang mendukung pembelajaran daring & 6 & $10 \%$ \\
\hline orangtua kurang sabar dan belum memahami pembelajaran bagi ABK & 7 & $12 \%$ \\
\hline Beberapa pembelajaran yang membutuhkan sentuhan sulit dilakukan & 2 & $3 \%$ \\
\hline ada siswa yang tidak memungkinkan home visit dan mengalami masalah dalam penguasaan IT & 4 & $7 \%$ \\
\hline orangtua pasif dan kurang responsif dan kooperatif pembelajaran daring & 10 & $17 \%$ \\
\hline
\end{tabular}

Berdasarkan Tabel. 19 kendala yang dimiliki oleh guru tidak jauh berbeda dengan yang dirasakan orangtua, seperti keadaan anak yang sulit diajar melalui daring karena menolak belajar via daring atau mood yang berubah, juga jaringan internet yang tidak stabil. Selain itu, ditemukan permasalahan terkait kondisi orangtua yang tidak mendukung PJJ seperti orangtua yang bekerja penuh waktu, kesulitan orangtua mengakses pembelajaran daring, hingga kurang kooperatif dan responsifnya orangtua. 


\section{JPK (Jurnal PendidikanKhusus), 16 (2), 2020 - 62}

Ossy Firstanti Wardany, Yulvia Sani

Berdasarkan permasalahan yang ada, guru menuliskan saran dan harapannya berkenaan dengan pembelajaran daring yang terangkum dalam Tabel 20.

Tabel 20. Saran dan Harapan Orangtua.

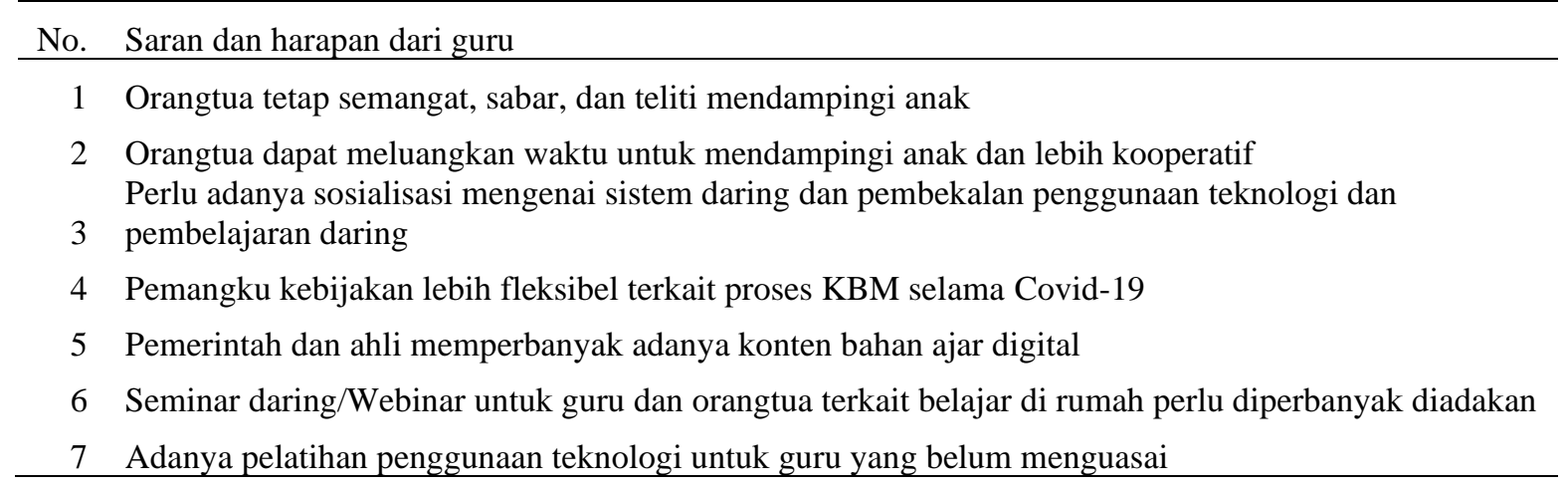

\section{Pembahasan}

Berdasarkan hasil survei pada guru dan orangtua, diketahui bahwa terdapat keragaman cara pembelajaran jarak jauh. Hasil ini sejalan dengan pendapat Cavanaugh (2006) bahwa ada berbagai cara melaksanakan PJJ yang interaktif seperti via chat, video conference, atau audio conference. Hasil survei menunjukkan bahwa aplikasi pesan seperti Whatsapp adalah aplikasi yang paling banyak digunakan. Sejalan dengan So (2016) bahwa pesan instan pada ponsel memberikan dukungan belajar dan mengajar bagi siswa. Selain itu, temuan Badan Pusat Statistik tahun 2018 menyebutkan bahwa di Provinsi Lampung, sebesar 90,33\% rumah tangga baik di kota dan di desa menguasai ponsel. Masyarakat yang dapat mengoperasikan ponsel dan kemudahan penggunaan pesan instan seperti whatsapp bagi orangtua maupun guru menjadikan alasan mengapa pembelajaran jarak jauh dengan komunikasi pesan instan lebih banyak daripada aplikai atau cara lain.

Pelaksanaan PJJ berdampak pada anak-anak yang sebelumnya tidak pernah belajar tanpa tatap muka dan tidak berinteraksi langsung dengan guru dan teman (Purwanto, dkk, 2020). Dampak ini tentu saja dirasakan oleh anak berkebutuhan khusus sehingga pendampingan orangtua memiliki peran penting. Hasil penelitian menyebutkan sejumlah kendala bagi orangtua dalam mendampingi dan bagi guru sebagai pengajar. Salah satu kendala yang ditemukan pada penelitian terkait PJJ yang menggunakan sistem daring adalah koneksi internet dan jaringan. Menurut Badan Pusat Statistik (2018) sebanyak 1975 desa dari sekitar 2435 desa di Lampung telah memiliki jaringan yang kuat. Selanjutnya, sebesar 60,41 \% keluarga yang memiliki akses internet. Belum meratanya jaringan dan koneksi internet serta tidak semua provider yang ada memiliki sinyal yang kuat di semua titik desa menjadi dasar kendala terkait sinyal. Salah seorang responden menyebutkan bahwa seringkali ia mengalami kehabisan kuota atau pulsa internet yang merupakan dampak dari adanya pelaksanaan PJJ.

Adanya PJJ mungkin saja membuat orangtua tidak mengeluarkan ongkos transportasi anak berangkat sekolah, tetapi pembelajaran daring menjadikan fasilitas internet menjadi pendukung utama yang membutuhkan tambahan kuota internet. Hal ini tentu saja tidak hanya dirasakan orangtua, tetapi juga guru. McVey (2008) mengatakan bahwa meski PJJ memberikan fleksibiltas dan aksesibilitas, tetapi hal itu dapat menjadi masalah apabila motivasi dan disiplin siswa rendah akibat guru yang kurang terlatih dapat menyebabkan pembelajaran menjadi kurang bermakna. Kenyataan bahwa belum semua guru melek teknologi dan harus beradaptasi dengan hal tersebut pun menambah kendala dalam PJJ yang bersifat daring. Sarana prasarana, fasilitas, dan kemampuan guru dalam pembelajaran jarak jauh begitu berpengaruh dalam keberhasilan PJJ. Kesulitan menyampaikan pembelajaran dapat mengurangi kebermaknaan pembelajaran itu sendiri.

Temuan terkait kendala yang dialami guru dan keluhan orangtua, dapat dikatakan bahwa guru harus dapat menciptakan iklim belajar yang kondusif meskipun terhalang jarak dengan siswa. Lingkungan belajar yang positif, adanya komunitas belajar, umpan balik yang konsisten, fleksibiltas dan sistem dukungan yang tepat adalah hal yang perlu dibangun guru (Chakraborty \& Nafukho. 2014). Untuk mewujudkan kelima hal tersebut guru membutuhkan pengetahuan, keterampilan, serta kreativitas dalam menerapakan pembelajaran. Akan tetapi, belum banyak guru yang mendapatkan bekal mengenai PJJ sebelum pandemi ini datang. Hal ini berkaitan dengan kenyataan bahwa kebutuhan PJJ sebelum 


\section{JPK (Jurnal PendidikanKhusus), 16 (2), 2020 - 63}

Ossy Firstanti Wardany, Yulvia Sani

pandemi bukanlah kompetensi paling penting yang harus dimiliki guru. Namun, ketika pandemi berlangsung kebutuhan guru untuk menguasai teknologi dan sistem pembelajaran jarak jauh adalah hal paling urgen sehingga diperlukan berbagai pelatihan penerapan PJJ untuk ABK bagi guru.

Kompetensi dan keterampilan guru tidak cukup untuk meningkatkan keberhasilan PJJ. Kerjasama dan pendampingan yang optimal perlu dilakukan. Sebagaimana pada dasarnya mendidik anak adalah bagian dari tugas orangtua. Sehingga, manajemen waktu dan fleksibilitas dalam membagi waktu bekerja dan membimbing anak haruslah menjadi perhatian orangtua. Subarto (2020) menegaskan bahwa orangtua memiliki peran penting dalam membangun regulasi diri anak dan penguatan selama pembelajaran di rumah. Regulasi diri dapat dilatih melalui penjadwalan, aturan di rumah yang disiplin, yang dapat disertai dengan pemberian penguat positif bagi anak. Namun, tidak semua orangtua memahami tentang manajemen perilaku, regulasi diri, atau bagaimana menyiapkan anak untuk siap belajar di rumah.

Tidak hanya guru yang memerlukan pelatihan dan peningkatan wawasan dan keterampilan, tetapi juga orangtua. Sehingga penting adanya kegiatan meningkatkan pendidikan pengasuhan pada orangtua anak berkebutuhan khusus. Setiawan (2020) menyebut bahwa pendidikan orangtua (education parenting) perlu dijadikan program kerja sama yang nyata antara sekolah dan orangtua. Berdasarkan pengamatan di media sosial, kegiatan pembekalan Parenting pun terlihat marak dilakukan oleh akademisi maupun prakitisi berkenaan pendampingan belajar yang dilakukan melalui webinar, kuliah Whatsapp (Kulwap) atau pun siaran langsung di Instagram atau Youtube. Hal ini menunjukkan bahwa adanya dukungan bagi guru maupun orangtua untuk dapat melaksanakan PJJ.

Pembelajaran jarak jauh pada anak berkebutuhan khusus memerlukan kesiapan orangtua dan guru. Berbagai kendala serta pengalaman yang dirasakan dapat menjadi indikator dalam memperbaiki dan meningkatkan kualitas PJJ. Guru dan orangtua memanglah aktor dari PJJ selama pandemi ini, sehingga penting bagi pemangku kebijakan, akademisi, dan pihak-pihak terkait lainnya untuk turut mendampingi dan membantu mereka. Karena guru dan orangtua harus terus meningkatkan kompetensi dan keterampilan yang dimiliki dalam mendampingi, mengajarkan, dan beradaptasi di tengah pandemi atau menghadapi transisi menuju kenormalan baru.

\section{SIMPULAN}

Hasil survei menunjukkan bahwa selama pandemi Covid-19, pembelajaran jarak jauh dilaksanakan dalam bentuk pembelajaran daring. PJJ memerlukan pendampingan dari orangtua dan pada pelaksanaannya masih ditemukan kendala terkait konektivitas internet, waktu yang dimiliki, keadaan emosi dan kesiapan anak belajar dari rumah, serta kompetensi dan kemampuan orangtua dalam pengasuhan anak dan pembelajaran anak berkebutuhan khusus di rumah. Sosialisasi sebelum PJJ telah dilakukan dan pelatihan bagi orangtua sudah diberikan oleh guru di berbagai sekolah, meskipun belum merata. Akan tetapi, kendala terkait sinyal, kondisi, peran, dan sikap orangtua dalam mendampingi anak menjadi permasalahan bagi guru pelaksanaan pembelajaran. Berlatar hal tersebut sangat penting bagi setiap guru dan orangtua untuk memiliki kompetensi dan keterampilan dalam mendampingi anak berkebutuhan khusus, mengakses teknologi, dan bekerja sama. Guru dan orangtua harus terus kooperatif dan aktif mengikuti pelatihan, webinar, atau lokakarya yang dapat meningkatkan pemahaman dan kompetensinya.

\section{DAFTAR PUSTAKA}

Badan Pusat Statistik. (2018). Statistik Komunikasi Indonesia 2018. Jakarta: Badan Pusat Statistik

Cavanaugh, C. (2006). Distance Learning. In N. J. Salkind (Ed.), Encyclopedia of Human Development (Vol. 1, pp. 382-383). Thousand Oaks, CA: SAGE Reference.

Chakraborty, M \& Nafukho, F.M , (2014). Strengthening student engagement: what do students want in online courses?. European Journal of Training and Development, Vol. 38 Iss 9 pp. 782 - 802 


\section{JPK (Jurnal PendidikanKhusus), 16 (2), 2020 - 64}

Ossy Firstanti Wardany, Yulvia Sani

Isworo, T. (2020, 28 Maret). Cegah Covid-19, Pemprov Liburkan Sekolah Sampai 22 April.

Lampost.co. Diperoleh 26 Juni 2020 dari https://www.lampost.co/berita-cegah-Covid-19pemprov-liburkan-sekolah-sampai-22-april.html

Kementerian Kesehatan RI .(2020). Pedoman Pencegahan Dan Pengendalian Coronavirus Disesase (Covid-19), Jakarta: Direktorat Jenderal Pencegahan dan Pengendalian Penyakit.

Laudato, N. C. (2002). Distance Learning. In R. R. Flynn (Ed.), Computer Sciences (Vol. 3, pp. 75-77). New York, NY: Macmillan Reference USA.

McVey, M. H. (2008). Distance Learning. In N. J. Salkind \& K. Rasmussen (Eds.), Encyclopedia of Educational Psychology (Vol. 1, pp. 261-267). Thousand Oaks, CA: SAGE Publications.

Morissan. 2012. Metode Penelitian Survei. Jakarta: Kencana

Purwanto, A., Pramono, R., Asbari, M., Hyun, C.C, Wijayanti, L.M, Putri, R.S, \& Santoso, B.S. (2020). Studi Eksploratif Dampak Pandemi COVID-19 Terhadap Proses Pembelajaran Online di Sekolah Dasar. EduPsyCouns: Journal of Education, Psychology and Counseling, 2(1), 1-12.

Setiawan, H. (2020, 20 Maret). Peran Orang Tua dalam Pembelajaran Daring. Suaramerdeka. Diperoleh 27 Juni 2020 dari https://suaramerdeka.news/peran-orang-tua-dalam-pembelajarandaring/

Sheposh, R. (2020). Coronavirus 2019 (COVID-19). Salem Press Encyclopedia of Health.

So, S. (2016). Mobile instant messaging support for teaching and learning in higher education. The Internet and Higher Education, 31, 32-42.

Subarto (2020). Momentum Keluarga Mengembangkan Kemampuan Belajar Peserta Didik Di Tengah Wabah Pandemi Covid-19. Adalah: Buletin Hukum dan Keadilan, 4 (1), 13-18

Sudaryo Y., Sofiati, M.A., Medidjati A., \& Hadiana, A. (2019). Metode Penelitian Survei Online dengan Google Forms. Yogyakarta: Penerbit Andi

Surat Edaran Mendikbud No 4 Tahun 2020 Tentang Pelaksanaan Kebijakan Pendidikan Dalam Masa Darurat Penyebaran Covid-19. Diakses melalui https://pusdiklat.kemdikbud.go.id/surat-edaranmendikbud-no-4-tahun-2020-tentang-pelaksanaan-kebijakan-pendidikan-dalam-masa-daruratpenyebaran-corona-virus-disease-covid-1-9/ pada 18 Juni 2020.

Tanduklangi, A \& Amri, C. 2019. Manajemen Sumber Daya Pembelajaran Bahasa Berbantuan Komputer: Computer Assisted Language Learning. DeePublish: Yogyakarta

Tim Detik (2020, 19 Maret). 1 Warga Lampung Positif Corona, Pernah Ikut Seminar Keagamaan di Bogor. Detiknews. Diperoleh 26 Juni 2020 dari https://news.detik.com/berita/d-4946267/1warga-lampung-positif-corona-pernah-ikut-seminar-keagamaan-di-bogor

\section{PROFIL SINGKAT}

Penulis pertama, Ossy Firstanti Wardany lahir di Lampung Selatan, 12 Maret 1994. Menempuh pendidikan S-1 di Prodi Pendidikan Khusus/Luar Biasa Universitas Sebelas Maret Surakarta pada tahun 2012 sampai dengan 2016. Lalu melanjutkan studi Magister Pendidikan Luar Biasa pada tahun 2016 sampai dengan 2018 di Universitas Sebelas Maret Surakarta. Sejak tahun 2019 hingga sekarang menjadi staf pengajar di Prodi Pendidikan Luar Biasa Universitas Muhammadiyah Lampung.

Penulis kedua, Yulvia Sani lahir di Payakumbuh 10 Juli 1990. Menempuh Pendidikan S-1 di Prodi Pendidikan Luar Biasa Universitas Negeri Padang tahun 2008-2012 dan melanjutkan studi Magister Pendidikan Khusus di Universitas Pendidikan Indonesia dari 2014-2016 . Sejak akhir tahun 2016 menjadi staf pengajar di Prodi Pendidikan Luar Biasa Universitas Muhammadiyah Lampung. 